\title{
THE EFFORT OF ABCGM TO ESTABLISH BUSINESS CULTURE IN WEST JAVA UNIVERSITIES THROUGH BUSINESS INCUBATOR
}

\author{
Ida Hindarsah ${ }^{1}$, Bulan Prabawani ${ }^{2}$, Sulistia Suwondo ${ }^{3,}$ Sutadi Triputra $^{4}$ \\ ${ }^{1}$ Business Administration Studies, Universitas Pasundan, Bandung, West Java, Indonesia \\ ${ }^{2}$ Business Administration Studies, Universitas Diponegoro, Semarang, Central Java, \\ Indonesia \\ ${ }^{3}$ Accounting Study Program, Politeknik Negeri Bandung, Bandung, West Java, Indonesia \\ ${ }^{4}$ Departement of Informatic, Universitas Muhammadiyah,Bandung,West Java,Indonesia \\ ${ }^{1}$ ida.hindarsah@unpas.ac.id \\ ${ }^{2}$ bulan@live.undip.ac.id \\ ${ }^{3}$ sulistiasuwondo@polban.ac.id \\ ${ }^{4}$ sutadi.triputra@umbandung.ac.id
}

\begin{abstract}
Indonesia is a developing country in Asia, whose economic development still depends on foreign investment. MSME is an alternative business unit that can encourage domestic economic growth that can be released from the dependence of foreign investment. The low number of MSMEs compared to other countries in Asia and the vulnerability of MSMEs unable to compete in the market in the era of globalization. Make the government fund various stakeholders to be established and develop business incubators, including universities. With the adoption of this policy, universities in West Java began to create and build business incubators. This article is intended to describe the process of establishing and developing a university business incubator in West Java as region of Sundanese people. The method used in this research is qualitative research with data collection techniques through data observation and literature study. The results of the study that discussed the establishment of a university business incubator in West Java were carried out in collaboration with lecturers with international non-profit organizations .
\end{abstract}

\section{Keywords: university business incubator, west java, Incubator establishment, incubator development}

\section{Introduction}

Indonesia is a developing country in Asia trying to transform into an emerging market country with an economic growth prospect of $5.1 \%$. This prospect is partly driven by Total Factor Productivity (TFP), which still depends on foreign investors' funds, even though becoming an emerging country requires more significant financing than domestic ones (Prima, 2019). Meanwhile, the fulfillment of domestic funds remains constrained by the high unemployment rate. Micro Small Medium Enterprises (MSMEs) is a business unit that can be used as an alternative for the government to boost its economy's productivity. Because the production of goods and services for SMEs has a large market share, it can absorb labor and reduce unemployment. Also, MSE economic activities contribute to Gross Domestic Income by $60 \%$ (Haryant \& Hidayah, 2018). However, the number of entrepreneurs in Indonesia is only around $3.1 \%$ of the total population, so if compared to other countries in Asia, Malaysia which reaches $5 \%$, Singapore is around $7 \%$, China $10 \%$, and Japan $11 \%$, this figure is still shallow (Mariani \& Anom, 2019).

Besides, most entrepreneurs or MSMEs players in Indonesia are still constrained by minimal resources, which makes their businesses vulnerable in facing market competition in the current global era. So that technology and innovation are skills 
demands that business actors need to master. Mastery of these skills cannot happen without assistance from an institution that helps business actors. Higher education is a social institution that provides scientific and professional education in specific disciplines through teaching and research activities. Higher education becomes a strategic institution to assist business actors by forming a business assistance agency called a business incubator. Since 2016 the Kemenristekikti has tried to encourage every university to have a business incubator, aiming to help the agency assist businesses in technology and innovation (Kemenristek / BRIN, 2018).

West Java is one of the provinces in Indonesia which has many MSMEs of approximately four million five hundred business units engaged in non-agricultural business, namely in wholesale and retail trade, repair and maintenance of motorbikes, industrial processing, provision of accommodation and supplies, food and Drink. Like MSMEs in other regions in Indonesia, MSMEs in West Java also face obstacles and challenges from various lack of resources at their disposal (BPS-West Java, 2016). This condition can also be seen in new entrepreneurs in starting their business, some of the problems faced include business planning, setting up an office, recruiting new members, marketing and financial problems including those faced by start-ups. Paul graham (2012), states that what is meant by a start-up is a company that is designed to develop quickly. A newly initiated company does not necessarily mean that a company must engage in technology, and obtain funds from investors. Start-ups develop rapidly and continue to innovate in the downstream process and commercialization of their products, so that they have competitive power and high efficiency. Based on this phenomenon, the role of entrepreneurship and business incubators is needed which has become an important part of developing innovative start-ups and increasing the MSME class which will have an impact on the Indonesian economy. Given the very large role of IB, the government has contributed to the creation of Business Incubator with the issuance of Presidential Regulation number 27 of 2013 concerning entrepreneurial incubators, then the birth of business incubators is also stated in the regulation of the minister of cooperatives and small and medium enterprises Number 24 of 2015. Business incubator services In general, incubators Business has $7 \mathrm{~S}$ functions, namely Space, Shared, Service, Support, Skill development, Seed capital, and synergy. Of course, this regulation was made as an effort to provide solutions, especially for business actors, both beginners and those who are doing business. The Business Incubator is one of the centers under certain institutions, both in the government and in the private sector. Established in an effort to develop independent and professional new entrepreneurs. This incubator also aims to maximize the entrepreneurial spirit by conducting various programs including training programs, workshops, mentoring and acceleration.

The existence of a Business Incubator is expected to be able to make a real contribution in fostering MSMEs in an integrated and sustainable manner, for a certain period of time until business actors are independent and able to adapt to the competitive and dynamic business world. For this reason, the incubator provides holistic services for novice, ongoing businesses, as well as solutions to profitable business problems, market accessibility, capital, and science and technology services. The incubation program will accelerate the success of business development through a series of structured programs starting from planning, implementation, and evaluation based on quality management principles and national and international standards. 
However, in its development the number of business incubators in Indonesia is currently still limited, according to the Ministry of Cooperatives and MSME's of the hundreds of incubators that have ever been established, in 2004 there were only 56 incubator units throughout Indonesia, most of which were carried out by universities, and of which only a few were active. Some of the things that have caused the implementation of business incubators in Indonesia to be not optimal are influenced by the following six factors: (1) national economic conditions that prioritize maintaining economic stability rather than encouraging industrial growth; (2) there is no policy that specifically regulates the Business Incubator, including how the model of mentoring is ideal, established, and effective in incubating the MSMEs it fosters; (3) lack of understanding of the importance of the role of the Business Incubator in creating new jobs and the growth of the business world; (4) Limited and short-term sources of funds; (5) do not have professional human resources in managing the Business Incubator; (6) limited physical facilities (infrastructure) in the implementation of the incubator function (Bank Indonesia 2006). Based on this phenomenon, several universities that are members of the ABCGM association (Academician, Business, Community, Government, Media) took the initiative to collaborate with 12 (twelve) universities in West Java. The purpose of this paper will be to discuss how universities in West Java build and develop a business incubator in the university environment.

\section{Method}

The type of research used in this study is an inductive qualitative method, namely an analysis based on specific events to ensure a general theory (Suriasumantri, 2005). The data is interpreted according to the analytical framework with collecting, compiling, and describing various data and factual information. Research with a qualitative approach aims to explain social phenomena by using an unstructured exploratory method with a small sample size to describe a problem situation (Management Association, 2020).

This study describes the stages of building a business incubator in universities in West Java. The research uses a qualitative approach to describe a phenomenon based on the researcher's interpretation (Bakry, 2016; Berg, 2001). Qualitative research has several characteristics in which researchers collect data in the field by interacting and observing objects directly. The researcher is the main instrument because the researcher collects his data through document testing, behavioral observation, and interviewing data sources, including interviews, observations, documents, and audio-visual information, to get a comprehensive understanding through inductive and deductive data analysis (Berg, 2001).

The data collection technique was carried out by observing the activities of Focus Group Discussion, representation of university representatives, and literature studies. The FGD participants consisted of Bandung Islamic University, Bandung Polytechnic, Pasundan University, Parahyangan Catholic University, Computer University, Widyatama University, Langlang Buana University, Alghifari University, Telkom University, LP3I Polytechnic Bandung, Nusantara Islamic University, and several other universities such as Subang, and Cirebon. The data is then analyzed based on the conceptual framework used by the author to conclude.

\section{Result and Discussion}

\subsection{Literature Review}

The theory is a series of definitions that can help get a systematic view that can justify a phenomenon. This article will discuss business incubators, MSMEs, or what can be equated with the term startup and its relationship with higher education institutions. Startups are built to produce a new product or service under extreme and uncertain conditions (Lipińska, 2018). Newly born startups are looking for a repeatable and scalable business model by putting forward new ideas in the market to be economically sustainable. In the early 
stages of its emergence, a startup faces various vulnerabilities to develop because it is small in institutional size and has various shortcomings in assets, finance, and human resources (Jr., Fernandes, Roberto Sbragia, \& Borini, 2019).

Business Incubator (BI) first appeared in 1959 in New York, United States. It established by Joseph L. Mancuso (Marchis, 2007) as a "silver bullet" to deal with problems and challenges faced by small businesses or startups (ERESIA-EKE, IWU, JAIYEOLA, \& MUSIKAVANHU, 2019) so that their businesses will be successful (Wang, Hung, \& Wang, 2013). According to the European Commission (2002), the broad understanding of IB provides a conducive environment for entrepreneurs by building and developing the entrepreneur's business (Indiran, Khalifah, \& Kamariah, 2017). IB is an institution or institution that provides business development services for startups that are just starting their business (Agibalov; \& Tkacheva, 2015). The business continues to grow sustainably (Kuryan, Khan, \& Gustafsson, 2018) because IB provides various assistance services to startups or SMEs that it fostered (Binsawad, Sohaib, \& Hawryszkiewycz, 2017). In other words, it can be said that the incubator business is a partner of a new business entity that is a social partner, which makes the new business entity aware of the know-how in running its business (Shaik, 2018).

The startup incubation process in BI goes through three stages. The first stage is startup creation (pre-incubation), which includes various activities required by entrepreneurs to build their business, including ideas, establishing business models, business plans, and other activities aimed at developing startups. The second is the incubation stage, which is the IB's services from the initial stage to the expansion stage until the startup is in its first three years until maturity. The services provided include financial access, direct coaching and mentoring, and specific training. The third is the expansion or postincubation stage, which is the stage where startups reach their maturity phase to operate independently and leave IB (Wang et al., 2013).
The Business Incubator as a model for the growth of new business units has advantages where the IB provides intensive education regarding business aspects (Syarif 2009). Hewick (2006) defines incubation as an effort to cultivate qualified entrepreneurs in a workspace managed by an institution called an incubator supported by business mentoring, training, networking, and funding activities to enable the fostered entrepreneurs to survive in a competitive business world. In Indonesia, the government's definition of a business incubator administratively can refer to the Presidential Regulation of the Republic of Indonesia Number 27 of 2013 concerning the Development of Entrepreneurial Incubators. In the Presidential Regulations, an incubator is defined as an intermediary medium that performs incubation efforts on tenants and has a physical building to facilitate tenant activities (Hasbullah et al., 2015).

The IB has four facility services: access to capital loans and equity participation, link building, creating internal equity funds and establishing cooperative relationships with various corporations (Sareen, 2019). Meanwhile, according to Almubaraki and Busler (2011), the services provided by the IB include basic business, marketing assistance, and networking activities, accounting or financial management, bank access, liaison with strategic partners, and liaison with investors (AlFattouh, nd), more specifically IB services for startups, namely: physical infrastructure, workspace services, financial support access, process support, and network access (Indiran et al., 2017; Kuryan et al., 2018).

In the broad sense, referring to the work of Lose and Kapondoro, a business incubator becomes an institution that has nine functions, those are housing for new businesses, business development, providing an environment for early development, providing initial needs (physical, emotional, and intellectual), commercialization of new products, providers of new business models, nurture new businesses and small businesses, service providers, and accelerate business start-ups. This function is achieved 
by the business incubator by running three services, namely: mentoring, training, and coaching (Lose \& Kapondoro, 2020).

Meanwhile, according to the Ministry of KUKM, the services provided by IBs to tenants include: 1) Space, namely space for tenant business activities; 2) Shared office facilities, namely the provision of office facilities that can be used together; 3) Service, namely in the form of guidance and management consulting; 4) Support, such as research assistance, and access to technology; 5) Skill Development tenants; 6) seed capital, namely the provision of initial business funds and efforts to obtain access to capital to financial institutions; and 7) Synergy, namely the creation of business networks both locally and internationally (Ministry of KUKM 2012).

So that the business incubator can become an agency that can accelerate, a knowledge park, and an innovation center, which essentially acts as a provider of resources, a support system that helps tenant businesses run their business. According to Amit and Zott (2001), the operation of a business incubator requires a business model in which there is content, structure, and transaction management designed to create value that can be used in running a business in terms of the various opportunities that exist. At least some literature divides business incubators into six types: the university incubator, the independent commercial incubator, the regional business incubator, the companyinternal incubator, the virtual incubator, and the corporate accelerator (Wang et al., 2013).

According to Smilor (1987), the affiliation system in the incubator apart from the entrepreneur himself. There are four other stakeholders affiliated with the business incubator, namely the private sector, universities, government, and non-profit, who help tenant companies create profits, develop the economy, create jobs, profitable companies, successful products, and technology diversification (ALAAALFATTOUH \& ALSALLOUM, 2017). The illustration described by Smilor as follows:

Image 1: Stakeholder Afiliation in the Business Incubator and their goals

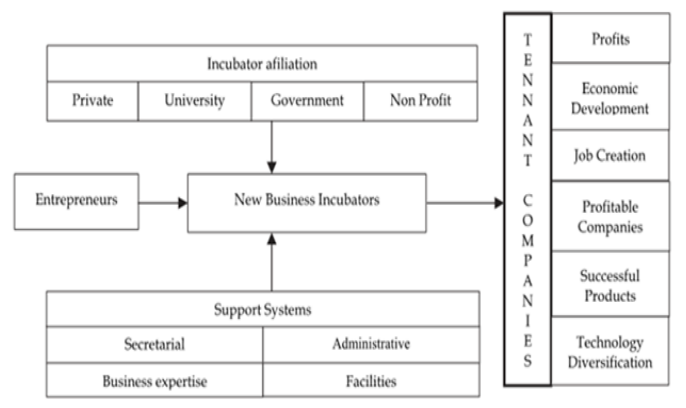

Source1: Alaaalfattouh \& Alsalloum, 2017) Meanwhile, according to Carayannis et al. (2005) and Shankar et al. (2018), based on the basic pattern of the base of the driving institutions, there are six types of Business Incubators, namely: (1) University Incubator, (2) Independent Commercial Incubator, (3) Regional Business Incubator / Regional, (4) Internal-Company Incubator, (5) Virtual Incubator, and (6) Accelerator Company (Tang, Walsh, Li, \& Baskaran, 2019). Because the startup ecosystem requires stakeholders in the IB, it will support ideas, research, operational assistance, mentoring, training, and social networks. Startups cannot be separated from the role of universities, financial organizations, service provider institutions, research organizations, large companies, and organizations. other supporters (Lipińska, 2018). There are key stakeholders in the IB consisting of various institutions such as business cluster institutions, academic institutions, government agencies, research laboratories, banks, and investors (Tang et al., 2019).

As institutions rich in research, universities are essential components whose role cannot be ignored in developing the country's economy. The university can generate innovation and quality human resources. With these elements, universities can act as agents of knowledge and technology transfer to academics and non-academics. The establishment of a business incubator is one of the university's strategies to play a role in maintaining or assisting small, medium enterprises, namely by establishing a university incubator business (Huda \& Rejito, 2020).

The university incubator is an IB that is run by a college or university. The objectives designed for this type of incubator follow the objectives designed by the university 
institution where the incubator is located. In general, according to Guerrero et al. (2014), the goals that university incubators focus on include commercialization and knowledge transfer of technology that arises from academic research. However, university incubators' features are no different from other types of incubators, such as services to target tenants, non-hierarchical structure transactions, and implementing marketbased governance mechanisms (Tang et al., 2019).

The university incubator business has existed since the 1990s as a university entrepreneurial concept. Entrepreneurial university is defined as the adoption of economic development accompanied by teaching and research. The development is considered more effective because there is a creative process, transfer of knowledge, and technology that can increase business productivity, improving a region's economic performance. University entrepreneurship requires innovative knowledge and entrepreneurial knowledge. Innovative knowledge focuses on understanding technology as the basis for commercial opportunities. In contrast, entrepreneurial knowledge focuses on understanding entrepreneurial processes and the networks used to access resources and expertise. So that innovative knowledge and entrepreneurial knowledge are two elements that must exist in the university incubator business (Nicholls-Nixon \& Valliere, 2019). The university is an institution that is different from other institutions that form business incubators because the university's mission is usually to prioritize the development of knowledge and the superiority of resources, stakeholders, and knowledge possessed. According to Andre (2016), at University BI, there are eight stakeholders, each of whom gets the benefit of having a university incubator, namely: (1) entrepreneurial students; (2) nonentrepreneurial students; (3) universities; (4) local influence; (5) government; (6) lecturers; (7) researchers; (8) bank/investor. The descriptions are as follows:

Table 1. Stakeholder Description

\begin{tabular}{|c|c|}
\hline Stakeholder & Obtained Benefit \\
\hline $\begin{array}{l}\text { Entrepreneur } \\
\text { Student }\end{array}$ & $\begin{array}{l}\text { 1. Get experience that adds value to job prospects } \\
\text { even though the startup is failing } \\
\text { 2. Opportunity to get profit } \\
\text { 3. Access to various incubator facilities reduces } \\
\text { the additional burden of business } \\
\text { 4. Network access } \\
\text { 5. understand the object being studied }\end{array}$ \\
\hline $\begin{array}{l}\text { Non- } \\
\text { Enterprenenur } \\
\text { Student }\end{array}$ & $\begin{array}{l}\text { 1. Gaining knowledge by observing startups } \\
\text { 2. Opportunity to work at startup }\end{array}$ \\
\hline University & $\begin{array}{l}\text { 1. Improve reputation by becoming a leader in } \\
\text { improving the quality of students and faculty } \\
\text { 2. Produce graduates with more qualifications } \\
\text { 3. Opportunity of getting }\end{array}$ \\
\hline Local business & $\begin{array}{l}\text { 1. Adding customers } \\
\text { 2. Add suppliers } \\
\text { 3. Increase the potential acquisition target }\end{array}$ \\
\hline Government & $\begin{array}{l}\text { 1. Creating more jobs } \\
\text { 2. increase tax revenue } \\
\text { 3. Reduce dependence on FDI (Foreign Direct } \\
\text { Investment) } \\
\text { 4. More autonomy nationally }\end{array}$ \\
\hline Lecturer/ & 1. Opportunity to share knowledge \\
\hline
\end{tabular}




\begin{tabular}{|l|cl|}
\hline Academician & 2. & increase connections with business people \\
\hline Researcher & \multicolumn{2}{|l|}{ Opportunity to commercialize findings } \\
\hline Bank/ Investor & $\begin{array}{l}\text { 1. } \\
2 .\end{array}$ & $\begin{array}{l}\text { Investment opportunities } \\
\text { concentrated place to find investment } \\
\text { candidates }\end{array}$ \\
\hline
\end{tabular}

Source: Andre, 2016

As technology continues to evolve, based on changing characteristics and its value proposition, IB is divided into three generations. The first generation was the initial phase of the formation of the IB. The institutional orientation was non-profit, with a multi-functional incubator that was not yet specialized, with activities still being carried out online and face-to-face. The goal the incubator is aiming for is economic development. The value proposition is still in the form of conventional services such as the provision of place infrastructure and performance support, with the rational thinking of economies of scale, namely a decrease in production numbers accompanied by an increase in production.

The second generation is an advanced phase when the IB has been specialized. There is a change in institutional orientation to become profit-oriented or to remain non-profit with activities based on technology. The aim of the incubator is the commercialization of innovation and technology. The values offered to customers or tenants include business and technology assistance, coaching, and training. This phase incubator's rational thinking is to accelerate the learning curve or the rate of progress of a person in gaining new experiences or skills. The third generation is an advanced phase after the second phase in which the institutional orientation can be profit or nonprofit. In this phase, as technology advances, the incubator is more focused on technology with activities based on high technology. The target in this phase is network access and becoming a business accelerator. The propositions offered by the incubator are access to technology, professional staff, and financial networks. Rational thinking of its activities is access to external resources, knowledge, and bureaucracy.

Meanwhile, the incubation process for SMEs that become tenants begins with the selection process by incubators. Then continue with monitoring and intervention process that will increase the value-added products. The last is graduation. The selection process is usually seen from the potential of the product market, the quality of the founding team, or the quality of the business model it has. And usually, university business incubators prioritize the MSMEs owned by students, how many MSMEs can accommodate students or the scope size of how many the tenant can learn through the incubation process carried out (Nicholls-Nixon \& Valliere, 2019).

Second, the monitoring process is carried out by improving tenant performance by observing specific progress, such as increasing the number of tenant customers, sales income. Finally, the graduation process usually occurs after the tenant has spent a certain period of incubation and mentoring carried out by the incubator to achieve tenant development targets (Nicholls-Nixon \& Valliere, 2019).

During the incubation period, the incubator will provide a business model that needs to be applied to its tenants depending on the tenant's needs or the standard of the incubator standard. The business model itself has a non-specific definition. However, briefly, the business model describes a company earning revenue, including managing its organizational structure, starting from creating, delivering, and providing company value. So it can be said that the business model is the company's business logic to get sustainable revenue (Hindarsah et al., 2020).

The canvas business model is one of the business models developed by Osterwalder, which maps out nine component blocks in a business model that looks at the company's internal and external conditions. The nine blocks consist of customer segment, value proposition, channel, customer relationship, revenue stream, key resources, key activities, key partnership, and cost structure. Customer segment is to classify the group of people to be reached as a 
market for the company's products or services. Second, the value proposition is the value offered to customers so that it becomes a reason for customers to switch to using the products or services offered by a company. Third, the channel is the channel how the company communicates with its customers to reach the targeted customer segment and distribute its products and services.

Fourth, the customer relationship, which is a block that describes the various relationships between the company and its customers with specific goals such as customer acquisition or increasing sales. Fifth, the revenue stream is a description of the flow of money obtained by the company from customers. Sixth, key resources a block that describes the assets needed to run a business in the form of physical, financial, or intellectual resources.

Seventh, key activities, namely blocks that describe essential activities carried out by companies so that their business runs which include the production of quality goods to handling customer complaints, eighth key partnerships, namely network blocks between companies with partners and suppliers. The ninth cost structure, namely the components of the costs required by the company in operating its business.

From the explanation of the theories above, this paper will focus on establishing a university incubator business. So, the theory will be used is limited to the formation and the stakeholders involved in the formation process.

\subsection{Discussion}

The establishment of a higher education business incubator in West Java implements government policy, namely the Ministry of Research, Technology, and Higher Education, which encourages universities to establish business incubators. UBI encourages higher education institutions, especially teaching staff in entrepreneurship or business study programs, to establish or run a business incubator. The establishment was carried out through a network collaboration of academics who are members of the ABCGM Penta helix collaboration (Academics, Business, Community, Government, Media).

Through the ABCGM network, the teaching staff contacted an international non-profit organization that focuses on empowering MSMEs, namely Uitzending Managers Program (PUM). PUM is a non-profit organization that assists by bringing in experts to destination countries. Since 2017 PUM has handled incubators providing services to startups in various countries. The participation of these five stakeholders in establishing a university business incubator is because many stakeholders will benefit from establishing a business incubator in the university environment-first, the student, both students who are doing business and who is not. The student will gain more experience in managing the business, the possibility of getting more profit by joining the incubation program, opening access to the use of various facilities provided by the incubator, and network access. As well as the means to understand the object of student study, whether entrepreneurial or not. Also the opportunity to work in the startups after they graduates.

Second, the university as a public institution will increase its reputation and increase the quality of resources, both students and teaching staff. Third, local entrepreneurs around the university will gain new market share, new raw material supply partners and increase the potential for acquiring new business entities.

Fourth, the government, which in the long term, is that tenants who are successfully incubated by the incubator will create new jobs, receive tax revenues, become free from dependence on foreign investment, and become more autonomous nationally. Fifth, academics will benefit from the opportunity to disseminate knowledge and connect them with business practitioners. Sixth, researchers can commercialize their findings. Seventh, banks or investors have new potential clients for capital investment. In its formation, the ABCGM Network and the initiators forming business incubators gathered and planned the establishment of incubators at their respective universities. After that, the ABCGM network then invited 
PUM as facilitators who became partners to help establish incubators in every private university in West Java.

When the fasilitator comes, the first step taken by the college incubator initiator network is mapping the institutions by grouping universities in the why-run business incubator stage and the how-to-run business incubator group as part of the public hearing. Why some group of universities that still do not have a business incubator? For the group of universities that already have a business incubator but have not run optimally. The grouping is intended to make it easier for the mediator (PUM) to identify problems or challenges the initiators face in communicating with policy authorities in higher education institutions.

Some tertiary institutions, that are in the how-stage complained about dynamics in running a business incubator, such as:

- the break with tenants who have become alumnee, whereas on the other hand alumni tenants are needed as a coaching staff

- independence of business incubators that have autonomy without intervention from the original higher education institution

- profit or non-profit institutional orientation

- collaboration of external stakeholders

- lack of understanding of management to run IB, and bureaucratic problems in institutions

Meanwhile, other universities shared their experiences on establishing relationships with incubator partners, getting revenue from incubator partners, and producing successful student startups. The third stage is the incubator business model's uniformity because the business model reflects what the incubator and customer want to achieve with clearly designed value innovations (Isabelle $\&$ Westerlund, 2016). The business model designed to be used by tertiary institutions in West Java is the Canvas Business Model. According to the IB initiators, Canvas Business Model (CBM) is easy to adapt and understand to business people. The design of the CBM for college IBs is slightly different from the MBK for business entities. For example, the key partners involve management, the Ministry of Research, Technology and Higher Education, the Indonesian Business Incubator Association (AIBI), an outside community consisting of alumni and local residents, and student startups.

Meanwhile, the key activity is a variety of continuous assistance. The value proposition is the provision of working and co-working spaces; customer relationships, namely building comfortable relationships with MSMEs or student startups with bazaar channels and social media. The IB college cost structure rests on the institutional budget.

According to PUM as a mediator and incubator coach for universities in West Java. University Business Incubator needs to analyze the stakeholders involved in the IB by selecting key partners who are in line and supporting the Incubator Business ecosystem, analyzing SWOT factors, and identifying external partners' needs such as corporations more prominent to startups and vice versa. So the incubator can bridge the interests of two parties to create a mutually beneficial ecosystem.

Then the need for periodic evaluation of UBI to form the maturity of IBs that provide services to startups or MSMEs to develop their business. Meanwhile, the revenue stream problem can be managed by planning the stable condition of the startup. That is fostered or by other means such as equity share because the IB does not provide support in the form of capital financing to its tenants but facilitates connecting with certain parties such as the government or financial and capital institutions (Allahar, 2016).

The emergence of UBI in West Java is an initiation of government policy. The definition of the term business incubator is still not fully understood by academic groups. Government policy in encouraging the establishment of an IB is usually an effort to reduce the unemployment rate by stimulating MSMEs' growth by commercializing technology carried out by universities and research institutions 
(Alinsunod, 2019). This can be seen from two groups of universities, namely why and how, which indicates two things. First, there is no higher education about the importance of a business incubator as an entrepreneurial laboratory facility for students. Second, the understanding and experience of academics about the role of business incubators is not yet complete. IB is an institution that provides services for entrepreneurs, namely physical infrastructure facilities, workspace services, access to financial support, process support, and network access. As part of the IB college educational institution, it is necessary to build a network with other stakeholders, namely the private sector, government, and non-profit organizations. For non-profit institutions, IB universities in West Java have done with PUM. This is because higher education incubators' success is not reflected in profit money but rather in social respect. Where university IBs can encourage startup progress through educational functions to improve and provide human resources that indirectly contribute to economic growth (Moleiro Martins, Abreu, \& M.F. Calado, 2019) macro.

In the FGD that was carried out in planning the establishment of a business incubator, several university representatives stated that establishing a business incubator at the university was to support MSMEs or startups owned by students and the community around campus. The reason is that the incubator provides services to its tenants in the form of mentoring know-how in running their business to grow. The participant's statement follows the concept that states that the business incubator is intended to support start-ups or SMEs that are just starting their business to survive in an uncertain market. An MSME will have a scalable business model with a clearer market share with the incubation process. So that start-ups or SMEs can successfully survive and develop. As in theory, university incubators have goals that follow the institution's goals so that their space is limited by bureaucracy and the authority of the institution's authorities. This can be seen from the emergence of complaints about problems related to institutional bureaucracy. Ideally, all stakeholders in a tertiary IB, namely: entrepreneurial students, non-entrepreneurial students, universities, local experts; government; lecturer; researchers; bank/investor. Connect well with each other in order to benefit from the existence of a business incubator.

Incubators for tertiary institutions in West Java are newly born institutions, which are still in the first generation phase so that their institutional orientation is still non-profit. This type of incubator is multi-purpose because it is still trying to gather and recruit tenants in various business fields. So far, UBI in West Java has only reached the incubation stage based on the incubation process. The tenants of alumni become alumni not because they have finished the incubation period but because the entrepreneurial student has graduated from college. Service activities are carried out in two ways, namely directly and through online media. Besides, the services provided are not far from conventional services because their function is more of a student laboratory. According to the writer, the rational thinking that underlies higher education institutions' movement is oriented to economies of scale and the learning curve.

Like a business unit or company, a business incubator also needs a business model that will guide the incubator to move. According to the IB initiators, Canvas Business Model (CBM) is easy to adapt and understand. The design of the CBM for college IBs is slightly different from the CBM for business entities. Like the CBM formulated by Osterwalder, the CBM adopted by the incubator also consists of nine components, namely customer segment, value proposition, channel, customer relationship, revenue stream, key resources, key activities, key partnership, and cost structure. Nevertheless, some elements in it are different. For example: First, the customer segment is entrepreneurship students, lecturers, and staff who will enter retirement, alumni that conduct businesses that want to be developed. Second, the Value Proposition that is proposing working and co-working space providers and capital access networks. Third, namely the channel by conducting bazaars, institutional collaboration, and the use of social media (Hindarsah et al., 2020). 
Fourth, customer Relationship build comfortable relationships with MSMEs or tenant startups. Fifth, revenue Stream is obtained through managed tenants such as share equity, payment of rent from tenants, a government grant program, or a higher education institution budget. Sixth, Key Resources include Intellectual capital, Human resources, working space.

The seven key Activities carried out are various coaching assistance activities, bridging the needs of startups and large corporations to create markets and networks for startups, periodic evaluation of IB programs. Eighth, the Key Partnership is University management; startups students; Kemenristekdikti; Indonesian Business Incubator Association (AIBI); alumni; local citizens; society; large corporations that support startups development. Ninth, Cost Structure, namely costs arising from the Preincubation, incubation, and post-incubation activities; manager, assistant, and coach fees; activities outside the incubation stage; room rent and energy expenses (inwall); apprenticeship and marketing activities (outwall). Based on the explanation above, the authors argue that higher education incubators in West Java are transitioning between the first and second generations. Because the incubators are a newborn institution with little experience, it will, on the other hand, be driven by advances in information and communication technology, accelerate the evolution of the incubators' accelerated phase. And the model business developed by UBI in universities in West Java is still immature because it is still plan not an executable blueprint.

\section{Conclusion}

MSMEs are business units used as an alternative by the government to boost economic productivity and reduce unemployment. The still low level of entrepreneurship in Indonesia and the number of MSMEs that have failed because they cannot compete in the global era have made the government encourage various stakeholders to form MSME companion institutions known as business incubators, including universities. Several universities in West Java have built and developed their business incubators.
The development and establishment of higher education business incubators in West Java are carried out through the collaboration of lecturers or teaching staff members of the Pentahelix ABCGM collaboration (Academics, Business, Community, Government, Media) also network with non-profit organizations PUM that focus on empowering MSMEs. The step taken is to map institutions by grouping universities that have no incubators and those that already exist. Second, by sharing knowledge and experiences to identify the problems faced by each incubator. The third is designing a business model that will be implemented in the operationalization of the IB. IB universities in West Java are relatively new IBs, so their operations have not been optimal. Deepening knowledge about IB, e.g., types of services provided to startups that become tenants. Optimization of social networks with various stakeholders such as large corporate governments, local communities, banking institutions, and various other service institutions is needed so that IBs can guide and produce successful startups until the post-incubation period.

\section{References}

Agibalov;, L. A. Z. A. V, \& Tkacheva, J. V. (2015). Conceptualization Lifecycle of Business Incubators. Mediterranean Journal of Social Sciences, 6(6), 300309.

https://doi.org/10.5901/mjss.2015.v6n6 s7p300

ALAAALFATTOUH, \& ALSALLOUM, O. (2017). VIRTUAL BUSINESS INCUBATORS IN SAUDI ARABIA. JOURNAL OF INTERNATIONAL ACADEMIC RESEARCH FOR MULTIDISCIPLINARY, 5(5). Retrieved from http://www.jiarm.com/JUNE2017/pape r30612

AlFattouh, A. A. (n.d.). Virtual Business Incubators in Saudi Arabia.

Alinsunod, J. P. (2019). Best Practices of Technology Business Incubators in the Philippines. International Journal of Advanced Trends in Computer Science and Engineering, 8(5), 235-2321. https://doi.org/10.30534/ijatcse/2019/7 0852019 
Allahar, H. (2016). THE EMERGENCE OF BUSINESS INCUBATORS AS ENTREPRENEURSHIP

DEVELOPMENT TOOLS: A SMALL COUNTRY EXPERIENCE.

International Journal of Economics, Commerce and Management, IV(9).

Andre, J. M. (2016). ISME SHOULD CREATE A BUSINESS INCUBATOR.

Berg, B. L. (2001). Qualitative Research Methods for the Social Sciences. Pearson/Allyn \& Bacon.

Binsawad, M., Sohaib, O., \& Hawryszkiewycz, I. (2017). Knowledge Sharing in Technology Business Incubators. 6TH INTERNATIONAL CONFERENCE ON INFORMATION SYSTEMS DEVELOPMENT (ISD2017 CYPRUS).

BPS-JawaBarat. (2016). Potensi Usaha Mikro Kecil Jawa Barat.

ERESIA-EKE, C., IWU, C. G., JAIYEOLA, A. O., \& MUSIKAVANHU, T. B. (2019). A Scrutiny of the Essence of Business Incubators in the Distribution Sector. Journal of Distribution Science, 17(6), 5-13. https://doi.org/10.15722/jds.17.6.20190 6.5

Haryant, D. M., \& Hidayah, I. (2018). Potret UMKM Indonesia: $\mathrm{Si}$ Kecil yang Berperan Besar. Retrieved April 24, 2020, from UKM Indonesia website: ttps://www.ukmindonesia.id/baca$\operatorname{artikel} / 62$

Hasbullah, R., Surahman, M., Yani, A., Almada, D. P., \& Faizaty, E. N. (2015). Peran Inkubator Bisnis Perguruan Tinggi dalam Peningkatan Kinerja Usaha UKM Pangan. Jurnal Ilmu Pertanian Indonesia (JIPI), April. https://www.researchgate.net/publicatio n/280931813_Peran_Inkubator_Bisnis Perguruan_Tinggi_dalam_Peningkata n_Kinerja_Usaha_UKM_Pangan_Role of Universty Bussiness Incubators on the Improvement_of_Food_SMEs Bussiness Performances

Hindarsah, I., Purwanto, B. H., Priadana, S., \& Fahrudin, A. (2020). The Owner Factor: An Innovation Element of Business Model Canvas by SMEs Rattan Industry in Cirebon Indonesia.
International Journal of Advanced Science and Technology, 29(6), 39633972.

https://www.researchgate.net/profile/Id a-

Hindarsah/publication/347906912 The Owner Factor An Innovation Eleme nt of Business Model Canvas by $\mathrm{S}$ MEs Rattan Industry in Cirebon Ind onesia/links/5fe6929592851c13febdb9 14/The-Owner-Factor-An-InnovationElement-of-Business-Model-Canvasby-SMEs-Rattan-Industry-in-CirebonIndonesia.pdf

Huda, N. N., \& Rejito, C. (2020). Modeling University Business Incubator For SMEs Digitalisation. Indonesian Journal of Information Systems, 3(1), 23. https://doi.org/10.24002/ijis.v3i1.3500

Indiran, L., Khalifah, Z., \& Kamariah, I. (2017). THE CHALLENGES OF BUSINESS INCUBATION: A CASE OF MALAYSIAN INCUBATORS. https://doi.org/10.15405/epsbs.2018.07. 02.51

Isabelle, D. A., \& Westerlund, M. (2016). No TitleBusiness incubation and business model innovation.

Jr, de M. O., Fernandes, C. C., Roberto Sbragia, M., \& Borini, F. M. (2019). Startups and Innovation Ecosystems in Emerging Markets (M. de M. Oliveira, F. R. Cahen, \& F. M. Borini, Eds.). https://doi.org/10.1007/978-3-03010865-6

Kemenristek/BRIN. (2018). Buka Forum IBT, Menristekdikti Akan Dorong Inkubasi Bisnis Teknologi di Perguruan Tinggi. Retrieved April 24, 2020, from webpage website: https://www.ristekbrin.go.id/kabar/buk a-forum-ibt-menristekdikti-akandorong-inkubasi-bisnis-teknologi-diperguruan-tinggi/

Kuryan, N., Khan, M. S., \& Gustafsson, V. (2018). Born globals and business incubators: a case analysis. International Journal of Organizational Analysis, 26(3), 490-517. https://doi.org/10.1108/IJOA-07-20171197

Lipińska, A. (2018). Areas and Forms of Operation of Academic Business Incubators alongside Startup 
Organizations.

PRZEDSIĘBIORCZOŚĆ

ZARZĄDZANIE, 423-440.

Lose, H., \& Kapondoro, L. (2020). COMPETENCIES FOR BUSINESS INCUBATORS IN A DISRUPTIVE CONTEXT: THE CASE OF SOUTH AFRICAN BUSINESS INCUBATORS. Academy of Entrepreneurship Journal, 26(4). https://www.researchgate.net/publicatio n/346034790 COMPETENCIES FOR BUSINESS_INCUBATORS_IN_A DISRUPTIVE_CONTEXT_THE_CĀS E_OF_SOUTH_AFRICAN_BUSINES S INCUUBATORS

Marchis, G. (2007). Fundamentals of Business Incubator Development.

Mariani, W. E., \& Anom, I. G. A. (2019). The Characteristic of Business Incubator Tenant. 3rd International Conference on Research of Educational Administration and Management (ICREAM 2019)， 400， 323-326. Atlantis Press.

Moleiro Martins, J., Abreu, A., \& M.F. Calado, J. (2019). Business Incubator and Economic Development. In Intellectual Property Rights - Patent [Working Title]. https://doi.org/10.5772/intechopen.885 $\underline{62}$

Nicholls-Nixon, C. L., \& Valliere, D. (2019). A Framework for Exploring Heterogeneity in University Business Incubators. Entrepreneurship Research Journal. https://doi.org/10.1515/erj2018-0190

Prima, B. (2019, February 26). Oxford Economic ramal Indonesia jadi negara emerging market terbesar ketiga di 2028. Kontan.Co.Id. Retrieved from https://nasional.kontan.co.id/news/oxfo rd-economic-ramal-indonesia-jadinegara-emerging-market-terbesarketiga-di-2028

Sareen, M. D. S. R. A. S. B. (2019). Assessing the effectiveness of business incubators. International Journal of Innovation and Learning, 26(2), 177194.

https://doi.org/10.1504/ijil.2019.10022 108

Shaik, M. (2018). Business incubation and firm performnce. AJANTA, VII(VI). https://www.researchgate.net/publicatio n/344076101_Business_incubation_an d_firm_performnce\#fullTextFileConte $\mathrm{nt}$

Tang, M., Walsh, G. S., Li, C., \& Baskaran, A. (2019). Exploring technology business incubators and their business incubation models: case studies from China. The Journal of Technology Transfer, 1-27. https://doi.org/10.1007/s10961-01909759-4

Wang, W.-B., Hung, Y.-C., \& Wang, C.-C. (2013). University-Industry Business Incubators in Taiwan. Open Journal of Business and Management, 01(01), 18. https://doi.org/10.4236/ojbm.2013.110 01 http://www.paulgraham.com/growth. htm 1 